Pawet FUĆ

Piotr LIJEWSKI

Eulasz RYMANIAK

Pawet DASZKIEWICZ

Michalina KAMIŃSKA

Natalia SZYMLET [0

Aleks JAGIELSKI

\title{
Analysis of exhaust emission measurements in rural conditions from heavy-duty vehicle
}

Road transport holds for the largest share in the freight transport sector in Europe. This work is carried out by heavy vehicles of various types. It is assumed that, in principle, transport should take place on the main road connections, such as motorways or national roads. Their share in the polish road infrastructure is not dominant. Rural and communal roads roads are the most prevalent. This fact formed the basis of the exhaust emissions and fuel consumption tests of heavy vehicles in real operating conditions. A set of vehicles (truck tractor with a semi-trailer) meeting the Euro V emission norm, transporting a load of 24,800 $\mathrm{kg}$, was selected for the tests. The research was carried out on an non-urban route, the test route length was $22 \mathrm{~km}$. A mobile Semtech DS instrument was used, which was used to measure the exhaust emissions. Based on the obtained results, the emission characteristics were determined in relation to the operating parameters of the vehicles drive system. Road emission, specific emission and fuel consumption values were also calculated.

Key words: heavy-duty vehicle, emission test, exhaust emission

\section{Introduction}

Road transport has been observed to have the dominant position in the structure of land cargo transport in the European Union countries for many years. In 2017, 85\% of all goods were transported using motor vehicles, and only $11.7 \%$ by rail. The share of inland waterway transport accounted for only $0.3 \%$ [8]. Such a configuration of the structure of cargo transport is the result of a number of factors. The most important one of them is the ability to deliver goods directly from the sender to the recipient only using one mode of transport. Currently, this is possible only with the use of road transport. This is difficult in other transport sectors because the rail and water infrastructure is not as extensive as road infrastructure. In most cases it is still necessary to also use motor vehicles to transport goods even when choosing a railroad or inland waterway as the main mode of transport. In this case, the most effective type of transport is intermodal transport using a single container unit throughout - like a car semi-trailer, container etc. This eliminates the need to unload and load the cargo itself, which extends the time and raises the transport cost.

Due to the successive increase in the number of transported goods with the use of motor vehicles in most European countries, there is a problem with the capacity of the main thoroughfares and the road network in smaller towns, which results in the increase of road congestion. It also indirectly results from the location of industrial and logistic centers often located far from the main road arteries.

The traffic intensity reduces of the efficiency of transport services (extending the time and increasing the cost of moving cargo) as well as having a negative impact on the natural environment - through the emission of harmful exhaust components from motor vehicles. In countries with developed road and logistics infrastructure, this problem is not as significant as in the case of countries such as
Poland, where this infrastructure is undergoing its quickest development stage in the current decades. According to the Transport Activity Results in 2017 report prepared by the Central Statistical Office [8] in Poland in 2017, a total of 2036267 thousand tons of cargo were transported overall, of which up to 1747266 thousand tons, accounting for $85 \%$, were transported using motor vehicles. Most of these transport activities took place in the country - the share of this type of transport reached over $80 \%$. Therefore, it seems reasonable to assess the impact of heavy vehicles performing transport work in diversified traffic conditions, done by measuring exhaust emissions using PEMS mobile analyzers [9]. This Measurements are currently performed for various groups of vehicles [4, 7] in the field of approval and research purposes [6]. In the case of heavy-duty vehicles, the measurements are aimed at assessing the exhaust emission and fuel consumption under various operating conditions urban driving, rural, an motorway [5, 9].

\section{Research methodology}

\subsection{Test route selection criteria}

Road infrastructure in Poland consists of national, provincial, county and communal roads. In 2017, its total length was $422302 \mathrm{~km}$, of which the largest share of 58\% were municipal roads (Table 1 ).

Table 1. Polish road infrastructure between 2016-2017 [8]

\begin{tabular}{|l|c|c|c|c|}
\hline \multirow{2}{*}{$\begin{array}{l}\text { Road } \\
\text { categories }\end{array}$} & \multicolumn{2}{|c|}{ Hard Surface roads } & \multicolumn{2}{c|}{ Unsurfaced roads } \\
\cline { 2 - 5 } & 2016 & 2017 & 2016 & 2017 \\
\hline National & 19388 & 19410 & 0.1 & 0.1 \\
\hline Regional & 28920 & 29083 & 43 & 41 \\
\hline District & 124944 & 124673 & 10275 & 10029 \\
\hline Communal & 246983 & 249135 & 115604 & 112588 \\
\hline
\end{tabular}

The smallest share in the road infrastructure that did not exceed $5 \%$ was made up by national roads. Based on this 
information, it can be concluded that the national road transport of goods runs mostly along the so-called second category roads. This is also due to the location of industrial centers, which are mostly located in small and medium towns along roads of this category.

The current tendency for the development of the industrial and logistics network is to build leading centers in locations referred to as industrial districts that are close to the main thoroughfares [1]. Taking into account current trends in transport problems, eg. flow and organization of traffic for various scenarios in national transport system is used programs for modelling this issues [2, 3]. The above facts were the main factor determining the choice of the test route on which emission measurements in real traffic conditions were made. The route used for research began in the industrial district of the city of Koło, where the largest industrial plants are located, and where several dozen heavy vehicles are handled daily (Fig. 1). This district is located by the provincial road no. 270 , which is also a transit route for motor vehicles with a permissible total weight over $3500 \mathrm{~kg}$ by the city of Koło. This route ends at the intersection with the national road No. 92 and passes into the provincial road No. 473. Both of these roads were included into the test route chosen by the authors, which ended at the A2 motorway interchange "Dąbie". The length of the route was $22 \mathrm{~km}$, of which driving in urban conditions was $10 \%$. The remaining part of the route was in extra-urban driving conditions.

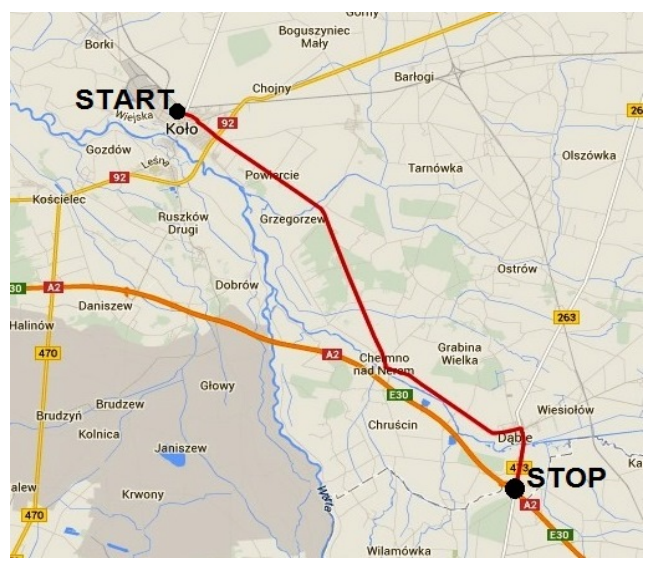

Fig. 1. The test route used in the on-road emission test of a heavy-duty vehicle [10]

\subsection{Research object}

For the research, the authors used heavy-duty truck (road tractors with semi-trailers) loaded with a cargo of 24,800 kg (Fig. 2). The object had a V8 $412 \mathrm{~kW}$ (560 KM) Euro V engine (Table 2). Vehicle was fitted with an automatic transmission of the $12+1$ configuration. Vehicle was also fitted with a driver monitoring system. The system, by a continuous analysis of signals from a series of sensors, provides real time hints and, upon end of trip, generates a report on the driving style.

The hints and the evaluation are presented on a display and have 4 categories: driving uphill, predicting, braking and gear shifts. The idea behind the system is to continuously improve the driving skills in terms of fuel consump- tion and proper use of modern solutions such as: automatic transmission, retarder or EBS (Electronic Braking System).

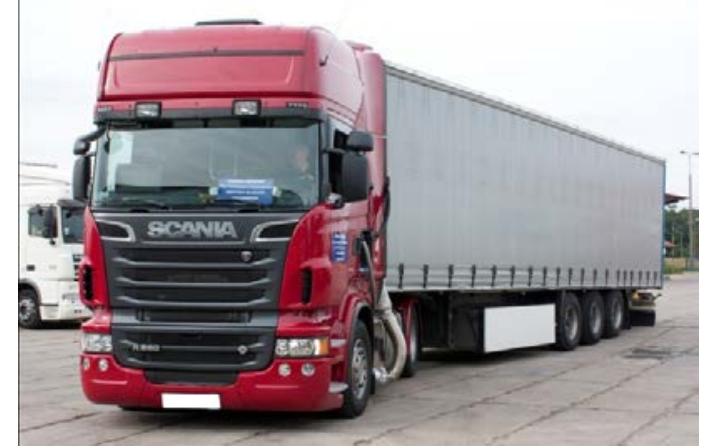

Fig. 2. The heavy-duty vehicle prepared to emission test

Table 2. Characteristics of vehicles used for the tests

\begin{tabular}{|c|c|}
\hline Parameter & Value \\
\hline \multicolumn{2}{|c|}{ Engine } \\
\hline Displacement & $15.6 \mathrm{dm} 3$ \\
\hline Number of cylinders/arrangement/ & $8 / \mathrm{V} 8$ \\
\hline Maximum power output & $412 \mathrm{~kW} @ 1900 \mathrm{rpm}$ \\
\hline Maximum torque & $2700 \mathrm{~N} \cdot \mathrm{m} @ 1000-1400 \mathrm{rpm}$ \\
\hline Unit power output index & $10.3 \mathrm{~kW} / \mathrm{t}$ \\
\hline Emission standard & Euro V \\
\hline Exhaust gas aftertreatment & SCR \\
\hline \multicolumn{2}{|c|}{ Vehicle and cargo } \\
\hline Transmission & Automatic $12+1$ \\
\hline Driver support system & SDS \\
\hline Tractor axle configuration & $4 \times 2$ \\
\hline Curb weight including trailer & $15200 \mathrm{~kg}$ \\
\hline Cargo weight & Steel \\
\hline Type of cargo & Canopy \\
\hline Type of trailer &
\end{tabular}

\subsection{Test equipment}

The Semtech DS mobile measuring device (Fig. 3) from the PEMS group was used to measure exhaust emission and fuel consumption and measured the following parameters:

a) concentrations of $\mathrm{CO}_{2}, \mathrm{HC}$ (hydrocarbons), $\mathrm{THC}$ (total hydrocarbons) and $\mathrm{O}_{2}$ (oxygen),

b) flue gas mass flow rate, temperature and pressure of exhaust gases,

c) temperature, pressure and humidity of the ambient air,

d) the speed and location of the vehicle,

e) basic parameters of the combustion engine operation recorded from the vehicle's on-board diagnostic system.

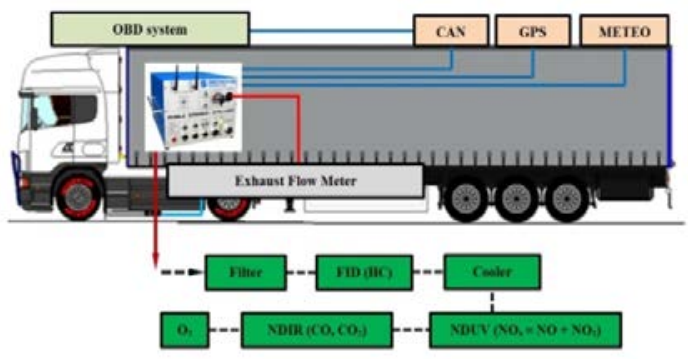

Fig. 3. The Semtech DS work schematic 
Semtech DS is one of the first compact systems for the measurement of exhaust emissions in real operating conditions of vehicles. It consists of a central analyzer unit, a flow meter for measuring the exhaust mass flow rate, as well as temperature and pressure of exhaust gases. A sample of exhaust gases from the exhaust system is supplied to the central analyzer unit through a heated elastic pipe, which maintains the temperature of $191^{\circ} \mathrm{C}$. This is to prevent the condensation of hydrocarbon fractions on the walls of the pipe .

\section{Test results - analysis and discussion}

Analyzing the characteristics of the heavy vehicle operating time share determined in the speed and acceleration intervals, the vehicle dynamics when travelling the selected route was found to be low, which is confirmed by the highest rate of acceleration from $0-0.6 \mathrm{~m} / \mathrm{s}^{2}$ representing $94 \%$ of total operating time (Fig. 4). During the tests, the vehicle moved at a speed of $0-24 \mathrm{~m} / \mathrm{s}(0-86 \mathrm{~km} / \mathrm{h})$, with the largest share of speeds recorded in the range of $16-24 \mathrm{~m} / \mathrm{s}$ $(58-86 \mathrm{~km} / \mathrm{h})$. The vehicle obtained an average speed of $54 \mathrm{~km} / \mathrm{h}$ on the route. Such a heavy vehicle traffic profile is characteristic for navigating the so-called second category roads, because they often run through villages and small towns with speed limits. This confirms the obtained significant share of the $(0-16 \mathrm{~m} / \mathrm{s}>$ speed range reaching $43 \%$. When driving on motorways and expressways, heavy vehicles obtain higher average speeds.

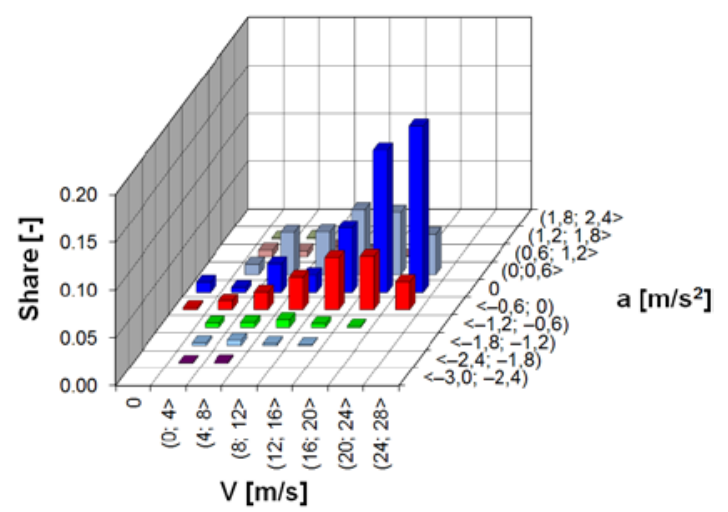

Fig. 4. Characteristics of the operating time share in the ranges of vehicle speed and acceleration

Referring the road conditions when conducting measurements to the heavy-vehicle engine operation characteristics confirms the presented thesis that the journey was characterized by a small variation in acceleration. This is mainly due to the engine running in a narrow range of crankshaft rotational speed - the largest share accounted for the engine speed of $1200 \mathrm{rpm}$ and reached 62\% (Fig. 5). At this speed, the engine operated mainly in the medium load range of $1200-2000 \mathrm{~N} \cdot \mathrm{m}$. These types of engine operating parameters can be defined as an approximate load characteristic, in the scope of which the engine obtains lower specific fuel consumption than in other operating points.

The $\mathrm{CO}, \mathrm{CO}_{2}$ and $\mathrm{NO}_{\mathrm{x}}$ emissions intensity were measured in the conducted road tests of a heavy vehicle. The HC emissions were intensity not measured, as earlier studies showed that in the case of heavy vehicles meeting the Euro $\mathrm{V}$ standard and higher, HC emissions are negligible. The highest values of $\mathrm{CO}$ emission intensity were registered in the urban part of the test drive (Fig. 6a). It was caused mainly by high acceleration variability of the heavy vehicle due to the shape of road infrastructure. In the extra-urban part, the drive was characterized by smaller changes in speed, which translated into lower CO emission intensity. This was especially visible in the 600-1180 seconds of drive duration range. In terms of the general engine characteristics, the highest values of $\mathrm{CO}$ emission intensity occurred at the maximum torque of $2400-2800 \mathrm{~N} \cdot \mathrm{m}$ in the engine speed range of 1000-1600 rpm (Fig. 6b).

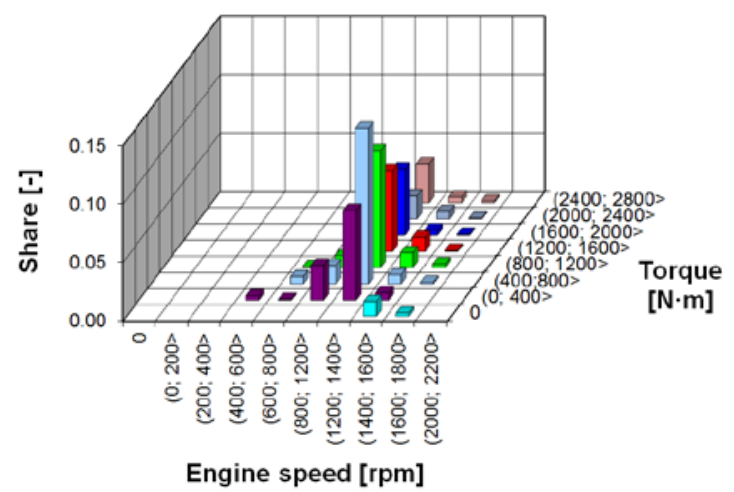

Fig. 5. Characteristics of the operating time share in the ranges of engine speed and load
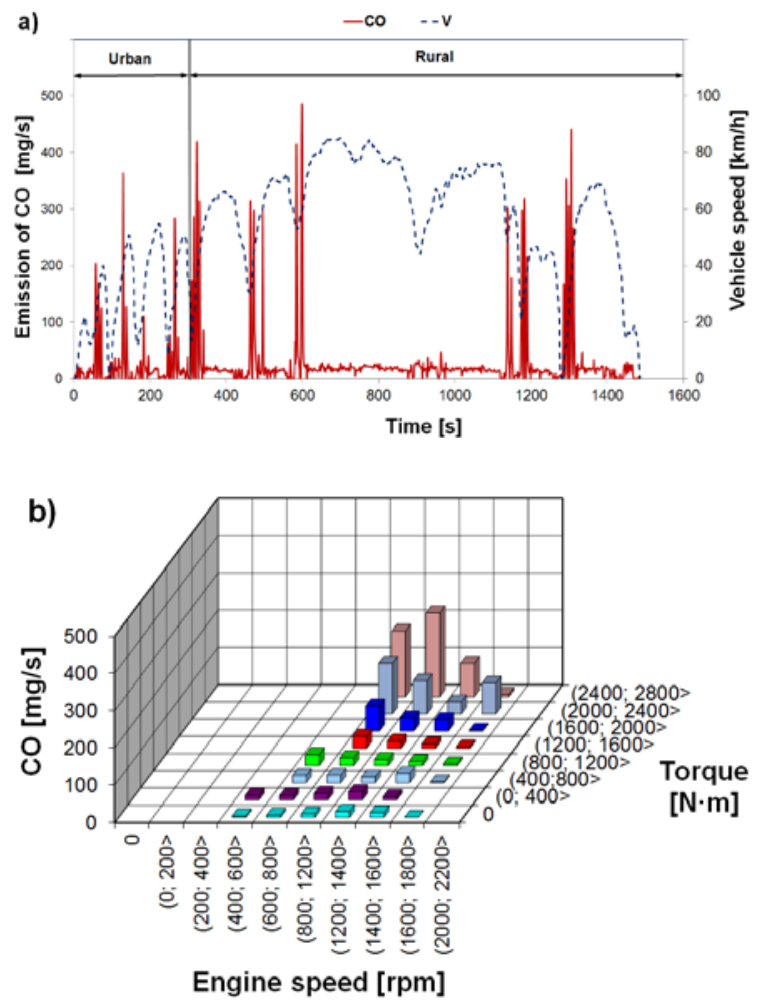

Fig. 6. The emission intensity of CO with vehicle speed (a) and emission intensity in engine speed and load intervals (b)

The $\mathrm{NO}_{\mathrm{x}}$ emission intensity characteristic was similar to the $\mathrm{CO}$ emission - the intensity increased with increasing vehicle speed (Fig. 7). In the urban part, the average $\mathrm{NO}_{\mathrm{x}}$ emission intensity value was $50.7 \mathrm{mg} / \mathrm{s}$, which compared to the rural section is an increase of $50 \%$. It should also be 
noted that the test was started with the engine being in a stabilized thermal condition (coolant temperature was $80^{\circ} \mathrm{C}$ ), which eliminated any impact that the engine warmup phase could have on the SCR (Selective Catalytic Reduction) conversion rate which is responsible for $\mathrm{NO}_{\mathrm{x}}$ reduction. $\mathrm{NO}_{\mathrm{x}}$ reduction reactions in the SCR catalytic system are preceded by the injection of $32.5 \%$ of urea into the outlet system, from which the ammonia constituting the reducer is formed.
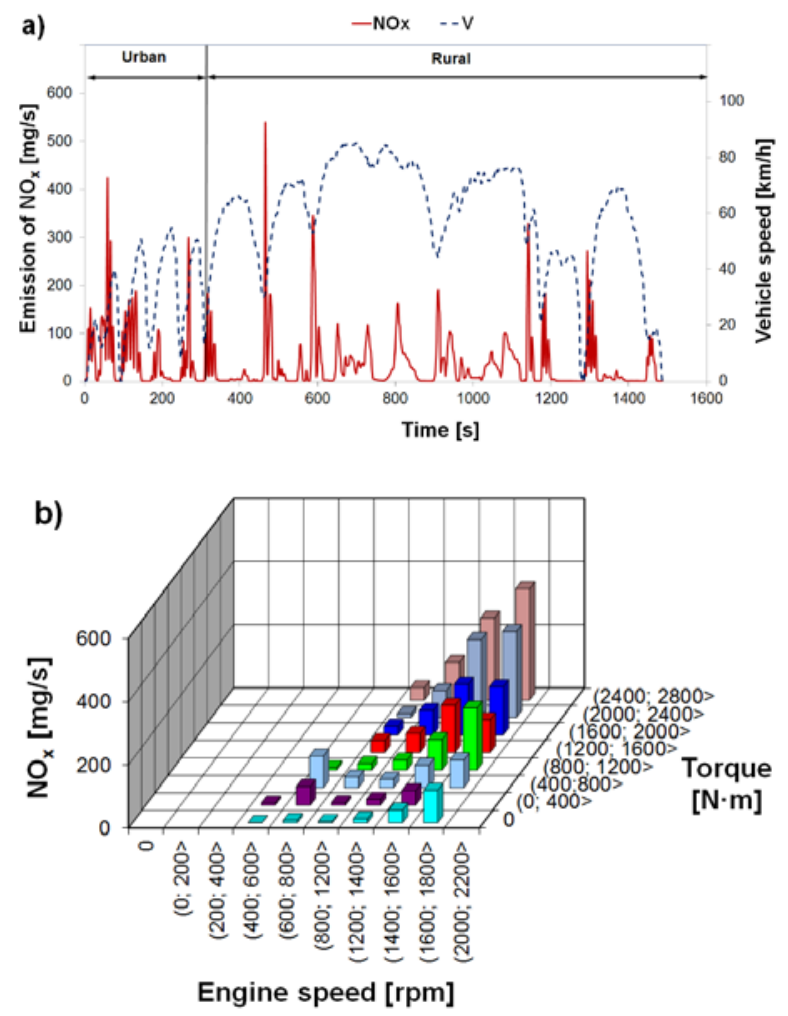

Fig. 7. The emission intensity of $\mathrm{NO}_{\mathrm{x}}$ with vehicle speed (a) and emission intensity in engine speed and load intervals (b)

This injection takes place only when the exhaust gas temperature is greater than $200^{\circ} \mathrm{C}$ and the $\mathrm{NO}_{\mathrm{x}}$ concentration exceeds $500 \mathrm{ppm}$. From this it follows that the main factor determining the intensity of $\mathrm{NO}_{\mathrm{x}}$ emissions during road tests was a relatively large proportion of the heavy vehicle starting to move after being stationary. This translated into higher crankshaft speed values and higher engine load - in the range $1600-2800 \mathrm{Nm}$ at $1400-1600 \mathrm{rpm}$. The highest $\mathrm{NO}_{\mathrm{x}}$ emission intensities were recorded in these combustion engine operating points.

In the case of $\mathrm{CO}_{2}$ emission intensity, its increase, related to the acceleration of the vehicle, was also recorded (Fig. 8a). $\mathrm{CO}_{2}$ emission is representative of the fuel consumption, so in sections where $\mathrm{CO}_{2}$ emission reaches maximum values the obtained fuel consumption is greatest. For a travelling heavy vehicle the highest fuel consumption occurs when accelerating, where the engine generates increased torque compared to when driving at a constant speed. The measurements carried out mirrored the relation described above (Fig. 8b). The highest values of $\mathrm{CO}_{2}$ emission intensity were obtained when the engine was operating under maximum load.
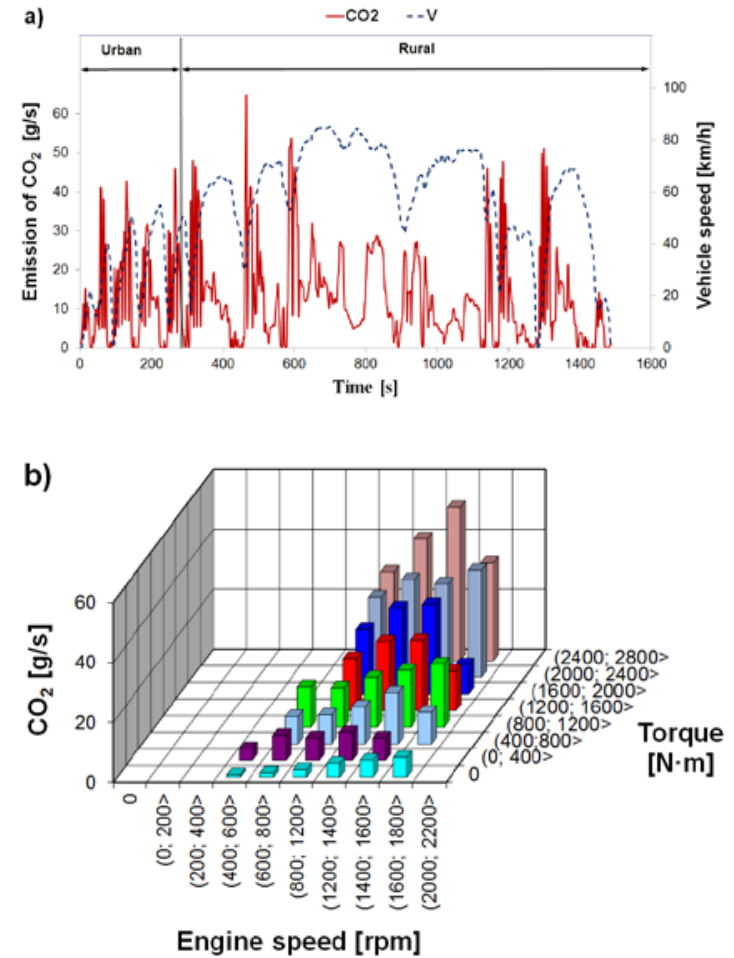

Fig. 8. The emission intensity of $\mathrm{CO}_{2}$ with vehicle speed (a) and emission intensity in engine speed and load intervals (b)

\section{Conclusion}

Based on the measured values of exhaust emission intensity, vehicle speed and the registered combustion engine operating parameters of the tested vehicle the road and specific emissions of $\mathrm{CO}, \mathrm{NO}_{\mathrm{x}}$, $\mathrm{CO}$ were determined as well as the fuel consumption value. The vehicle road emission values were:

a) $\mathrm{CO}-1.7 \mathrm{~g} / \mathrm{km}$;

b) $\mathrm{NO}_{\mathrm{x}}-2.4 \mathrm{~g} / \mathrm{km}$;

c) $\mathrm{CO}_{2}-836.9 \mathrm{~g} / \mathrm{km}$.

While the specific emission values were:

a) $\mathrm{CO}-1.3 \mathrm{~g} / \mathrm{kWh}$;

b) $\mathrm{NO}_{\mathrm{x}}-1.8 \mathrm{~g} / \mathrm{kWh}$;

c) $\mathrm{CO}_{2}-605.1 \mathrm{~g} / \mathrm{kWh}$.

On the test route the vehicle obtained a fuel consumption of $30.9 \mathrm{dm}^{3} / 100 \mathrm{~km}$. Based on the Authors own experience in road emission tests of heavy vehicles it was concluded, that the obtained fuel consumption on the extraurban route was small compared to the mixed driving conditions. Previous research conducted by the authors [5] done using the same vehicle in conditions of combined urban and extra-urban driving can be used as an example. On said route the fuel consumption obtained was 37.1 $\mathrm{dm}^{3} / 100 \mathrm{~km}$, which was $20 \%$ higher compared to the value for extra-urban driving conditions. Comparing the specific exhaust emission values of $\mathrm{CO}$ and $\mathrm{NO}_{\mathrm{x}}$ from the test drive to the limit values defined in the Euro V norm it was concluded, that these values are below the set limit. Hence, despite the fact that the tests were performed on so-called second category roads, the test drive was characterized by small variability of vehicle acceleration values, which in turn resulted in relatively small specific emission values of $\mathrm{CO}, \mathrm{NO}_{\mathrm{x}}$ as well as low fuel consumption of the heavy vehicle. 


\section{Acknowledgements}

The research was funded by European Union from European Regional Development Fund through the National Centre for Research and Development (Narodowe Centrum Badań i Rozwoju) - research project within the Smart
Growth Programme (contract No. POIR.04.01.02-000002/18).

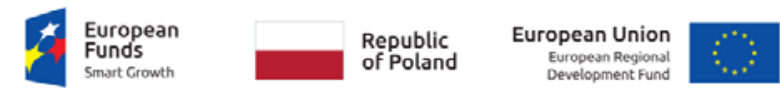

\section{Nomenclature}

a acceleration

CAN Controller Area Network

EBS Electronic Braking System

GPS Global Positioning System

PEMS Portablem Emission Measurement System
$\mathrm{S}_{\mathrm{j}} \quad$ share

SCR Selective Catalytic Reduction

SDS Driver Support System

$\mathrm{T}$ torque

$\mathrm{V} \quad$ velocity

\section{Bibliography}

[1] JACYNA, M. System Logistyczny Polski. Uwarunkowania techniczno-technologiczne komodalności transportu. Oficyna Wydawnicza Politechniki Warszawskiej, 2012.

[2] JACYNA, M., MERKISZ, J. Proecological approach to modelling traffic organization in national transport system. Archives of Transport. 2014, 30(2).

[3] JACYNA-GOŁDA, I., ŻAK, J., GOŁĘBIOWSKI, P. Models of traffic flow distribution for various scenarios of the development of proecological transport system. Archives of Transport. 2014, 32(4).

[4] MERKISZ, J., DOBRZYNSKI, M., KUBIAK, K. An impact assessment of functional systems in vehicles on $\mathrm{CO}_{2}$ emissions and fuel consumption. MATEC Web of Conferences. 2017, 118.

https://doi.org/10.1051/matecconf/201711800030

[5] MERKISZ, J., FUC, P., LIJEWSKI, P. et al. Impact of application type of engine in heavy-duty vehicle for $\mathrm{CO}_{2}$ CO emission and fuel consumption. Prace Naukowe Politechniki Warszawskiej-Transport. 2013, 98.
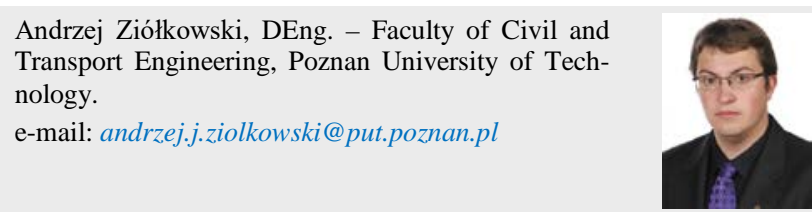

Prof. Paweł Fuć, DSc., DEng. - Faculty of Civil and Transport Engineering, Poznan University of Technology.

e-mail: pawel.fuc@put.poznan.pl

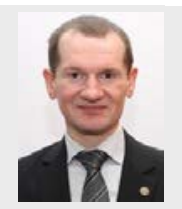

Prof. Piotr Lijewski, DSc., DEng. - Faculty of Civil and Transport Engineering, Poznan University of Technology.

e-mail: piotr.lijewski@put.poznan.pl

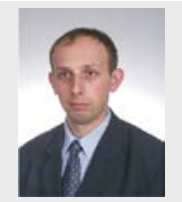

Łukasz Rymaniak DEng. - Faculty of Civil and Transport Engineering, Poznan University of Technology.

e-mail: lukasz.rymaniak@put.poznan.pl
[6] MERKISZ. J., KOZAK M., LIJEWSKI, P. et al. Exhaust emissions from heavy-duty vehicles under actual traffic conditions in the city of Poznan. Asia Pacific Automotive Engineering Conference. Bangkok. SAE Technical Paper 2013-01-0119, 2013. https://doi.org/10.4271/2013-01-0119

[7] PIELECHA, J., JASINSKI, R., MAGDZIAK, A. Practicability of passenger vehicle driving emission tests according to new European Union procedures. MATEC Web of Conferences. 2017, 118.

https://doi.org/10.1051/matecconf/201711800021

[8] Transport - wyniki działalności w 2017 r. Główny Urząd Statystyczny. Warszawa 2018.

[9] QUIROS, D.C., THIRUVENGADAM, A., PRADHAN, S. et al. Real-world emissions from modern heavy-duty diesel, natural gas, and hybrid diesel trucks operating along major California freight corridors. Emission Control Science and Technology. 2016, 2. https://doi.org/10.1007/s40825-0160044-0

[10] http://gpsvisualizer.com (access 15.12.2018).

Paweł Daszkiewicz, DEng. - Łukasiewicz Research Network - Rail Vehicles Institute „TABOR” in Poznań.

e-mail: pawel.daszkiewicz@tabor.lukasiewicz.gov.pl

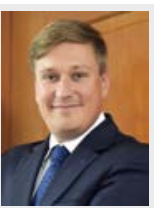

Michalina Kamińska, MEng. - Faculty of Civil and Transport Engineering, Poznan University of Technology.

e-mail: michalina.kaminska@put.poznan.pl

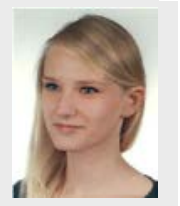

Natalia Szymlet, MEng. - Faculty of Civil and Transport Engineering, Poznan University of Technology.

e-mail: natalia.r.szymlet@doctorate.put.poznan.pl

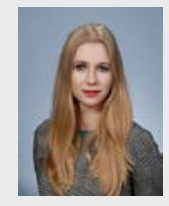

Aleks Jagielski, MEng. - Faculty of Civil and Transport Engineering, Poznan University of Technology.

e-mail: alexjagielski@gmail.com 